\title{
Weathering the Global Financial Crisis: Reflections on the Capacity of the Institutions of Australian Governance.
}

\author{
Dr Anne Tiernan \\ Department of Politics and Public Policy \\ Griffith University \\ Nathan, Queensland, Australia, 4111 \\ Email: a.tiernan@griffith.edu.au
}

Paper prepared for presentation at the American Political Science Association Annual
National Conference, Washington DC, September 1-6, 2010

[Draft: Not for citation without permission] 


\begin{abstract}
The global financial crisis (GFC) of 2008 sent the economies of major developed nations into freefall. As credit markets froze and investor and consumer confidence collapsed to levels not seen since the Great Depression, governments clamoured to develop policies and interventions aimed at preventing wholesale economic meltdown.

The Australian economy has come through the crisis relatively unscathed. In contrast to most other advanced economies, Australia avoided recession and, despite dire forecasts, has experienced only modest increases in rates of unemployment. Consumer confidence has recovered, investment is returning and the economy has performed consistently above expectations.

What accounts for Australia's success in navigating the global financial crisis? Economists will emphasise the combination of monetary and fiscal policy responses - significant cuts to interest rates, large stimulus packages, bank guarantees and other stabilising measures that were rapidly deployed as the crisis unfolded; the underlying strength of the nation's economy, surplus budgets, comparatively low rates of debt and effective prudential regulation.

Each of these was undoubtedly crucial, but as this paper argues, features inherent to the institutions of Australian governance must also be taken into account. This paper examines the structures of advice and support to Australian decision-makers that enabled decisive action to be taken and decisions implemented as the financial crisis loomed. It highlights the significance of the economic policy settings established by successive Australian governments, supported by a cadre of economic advisers - career officials and partisans, whose experience and institutional memory proved valuable to the newlyelected Labor government.

The paper argues that Australia's success owes much to timely and effective policy responses deployed quickly as the financial crisis loomed. The government's pre-emptive and aggressive response to the global financial crisis and the design of its fiscal policies was supported and enabled by an advisory system that had prepared for and which consciously drew on the lessons learned during earlier downturns. It concludes that the policy learning of key actors within the advisory and decisionmaking system was significant in helping to position Australia's economy to withstand the most significant economic shock since the Great Depression.
\end{abstract}

Keywords: Australia, financial crisis, policy advice, policy learning. 


\section{Introduction}

The global financial crisis of late 2008 sent the economies of major developed nations into freefall. As credit markets froze and investor and consumer confidence collapsed, governments clamoured to develop policies and interventions aimed at preventing wholesale economic meltdown. We know from the published accounts of those involved that the Labor government of Prime Minister Kevin Rudd, elected in November 2007, had been preparing for the worst from early 2008, well in advance of official advice and forecasts (see, for example, Taylor and Uren 2010). When Lehman Brothers collapsed in September 2008, Australian policy-makers were primed; they acted swiftly to implement timely and effective monetary and fiscal policy responses that allowed the Australian economy to consistently defy the effects of the global financial crisis (GFC) being experienced so dramatically in other countries.

Nobel Prize winning former Chief Economist of the World Bank, Joseph Stiglitz (2010b) has noted that Australia had the 'shortest and shallowest of the downturns of the advanced industrial economies'. It alone of 33 advanced economies counted by the International Monetary Fund (IMF) did not experience recession in 2009. Instead the economy grew by 1.3 per cent, a rate 4.5 per cent greater than the advanced economy average (Swan 2010a). By May 2009, the combined effects of a dramatic easing of monetary policy, ${ }^{1}$ together with unprecedented fiscal stimulus measures were yielding positive results. The decline in stockmarket values, which had fallen by 40 per cent since October 2008 was arrested; the Australian dollar, which had fallen almost 30 per cent against the Greenback recovered. House prices which had dropped by 4.5 per cent began to strengthen, ${ }^{2}$ buoyed by a temporary increase in the First Home Owners' Grant from $\$ 7,000$ to $\$ 21,000$. Unemployment peaked at 5.8 per cent, well below Treasury forecasts that it may reach between 8 and 10 per cent (Kennedy 2009, 8). It fell for ten consecutive months before increasing by 0.2 per cent in July 2010 to the current level of 5.3 per cent. ${ }^{3}$

It is estimated that without stimulus measures, the Australian economy would have contracted in the December, March and June quarters with a corresponding fall in GDP of 1.3 per cent for the year 2008/09. Positive assessments of Australia's performance relevant to other economies are believed to have supported domestic consumer confidence (Henry 2009, 3), cushioning the retail and housing

\footnotetext{
${ }^{1}$ Interest rates were slashed by 4.25 per cent between September 2008 and April 2009.

2 This was twice the rate of decline in the US (Garnaut 2009, 145).

3http://www.abs.gov.au/AUSSTATS/abs@.nsf/mediareleasesbyCatalogue/46DFE12FCDB783D9CA256B740082AA6C?Ope ndocument
} 
sectors and forestalling a potential collapse in aggregate demand. Eslake $(2009,235)$ argues that 'not only did the timing of the successive Australian fiscal packages turn out to be unusually appropriate, their magnitude and composition contributed significantly to their effectiveness'.

The Australian economy's success in weathering the crisis was confirmed when the Reserve Bank became the first in the world to lift interest rates from their 'emergency lows'. They have risen since October 2009 to stabilise at the current cash rate of 4.5 per cent. ${ }^{4}$ Indeed so little have Australians been affected by what analysts agree was the most significant economic shock since The Great Depression, some have speculated that, for many of them, the GFC 'never happened' (Taylor and Uren 2010). This is something of an irony given Australia's economic performance is the envy of many nations still grappling with the bitter legacy of the global downturn - low growth, high rates of unemployment, staggering levels of public debt and fears of a 'double-dip' recession.

What accounts for Australia's success in navigating the global financial crisis? Economists have emphasised the combination of monetary and fiscal policy responses - significant cuts to interest rates, large government stimulus packages, bank guarantees and other stabilising measures that were rapidly deployed as the crisis unfolded; the underlying strength of the nation's economy, surplus budgets, comparatively low rates of debt and effective prudential regulation.

Each of these was undoubtedly crucial, but as this paper argues, features inherent to the institutions of Australian governance must also be taken into account. This paper examines the structures of advice and support to Australian decision-makers that enabled decisive action to be taken and decisions implemented as the financial crisis loomed. It argues that Australia's success owes much to timely and effective policy responses. The government's pre-emptive and aggressive response to the global financial crisis was driven by political leaders keenly attuned to international developments and anxious to avoid the fate of an earlier Labor government. An advisory system that had prepared for and which consciously drew on the lessons learned during earlier downturns enabled monetary and fiscal policy responses to be rapidly deployed.

While policy interventions were decisive, it is important to recognise that Australia entered the GFC in better shape than many comparable economies. It had enjoyed 17 years of uninterrupted economic growth, underpinned by demand for commodity exports from its rapidly growing Asian neighbours

\footnotetext{
${ }^{4}$ http://www.rba.gov.aul [Accessed 16 August 2010].
} 
(Kennedy 2009). ${ }^{5}$ It had low levels of public debt, relatively high interest rates, a strong, profitable, well capitalised and well regulated banking sector that maintained prudent lending practices and AA credit ratings $^{6}$ (Eslake 2009; Hawtrey 2009). These favourable settings were the product of economic policies pursued by successive Australian governments, supported by a cadre of economic advisers - career officials and partisans, whose experience and institutional memory proved valuable to the newlyelected Labor government. The paper concludes that the policy learning of key actors within the advisory and decision-making system are significant in explaining Australia's experience of the GFC.

The structure of the paper is as follows. The first part of the paper describes how Australian policymakers responded to the global financial crisis. It provides the background and context for the analysis that informs the second and main part of the paper. The final section considers the significance of policy learning among key actors and institutions in shaping Australia's response to the crisis of 2008 and 2009.

\section{Australia's response to the GFC}

The Rudd government was elected in November 2007. The Australian Labor Party (ALP), long characterised by its opponents as irresponsible economic managers, had wrong-footed the Coalition government of Prime Minister John Howard during the election campaign by dramatically refusing to match its 'reckless spending' and by embracing 'economic conservatism'.7 Labor had been in opposition for 11 years. Only two members of the incoming ministry had prior experience, having been ministers in the Hawke (1983-1991) and Keating (1991-1996) governments, but many had political, parliamentary and governmental experience (see Tiernan and Weller 2010). While they were learning their jobs and making the transition to government, the Rudd ministry was also assuming responsibility for a looming threat, the first signs of which were already evident. ${ }^{8}$ The sub-prime mortgage crisis that had paralysed credit markets in the United States had begun to infect world markets. As institutions collapsed, the loss of confidence became self-reinforcing, stoking fears that what hitherto had been

\footnotetext{
${ }^{5}$ Commodities account for almost 60 per cent of total exports. Australia's exports of commodities actually rose after the onset of the GFC, largely due to demand from China (Eslake 2009, 232).

${ }^{6}$ Four out of nine AA rated banks are Australian.

7 The centrepiece of the Coalition's election strategy was a promise of $\$ 34 \mathrm{~B}$ in tax cuts to be delivered over three years. Citing the need for economic restraint in the face of rising inflation and interest rates, Kevin Rudd shocked his opponents and commentators alike when he announced Labor would not match the government's commitment (Taylor and Uren 2010, 16). Rudd proudly declared himself an 'economic conservative' determined to reclaim Labor's rightful record as the party of economic reform and fairness.

${ }^{8}$ Garnaut $(2009,94)$ reports that the US Federal Reserve records 7 February 2007 - the day that Freddie Mac declared it would no longer buy sub-prime mortgages as the first salient date of 'the Great Crash'.
} 
seen as a North American crisis, could threaten other economies in a globally interconnected financial system.

In opposition, Labor had been primarily concerned about capacity constraints in Australia's booming economy and the spectre of rising inflation. In its Pre-election Economic and Fiscal Outlook, the Treasury $(2007,1)$ forecast that 'despite the ongoing effects of drought and heightened downside risks to the world economic outlook', the economy would grow by 4.5 per cent in 2007-08. In an effort to keep inflation within the target range of two to three per cent, the Reserve Bank of Australia had begun progressively tightening interest rates - they rose by 3.25 percentage points between April 2002 and March 2008, including a further 0.25 basis points during the November 2007 election campaign and then again by the same rate in February and March 2008. While other countries approached zero interest rates, in Australia they remained steady at 7.25 per cent until September 2008 - providing considerable flexibility in the event monetary easing was required.

By virtue of its geographic remoteness, its open, trade-exposed economy and history of involvement in multilateral fora, Australian ministers travel extensively and cultivate their networks overseas. ${ }^{9}$ From the earliest months of the new government's tenure, discussions with international counterparts highlighted serious concerns about the likely fallout from the sub-prime crisis. So concerned was the Prime Minister about the pessimism being expressed overseas, that in late February 2008, after only three months in office, he asked the Secretary of the Treasury, Dr Ken Henry, what from his perspective would be the worst case scenario. Henry, who had been Secretary to Treasury since 2001, and had worked previously as an economic adviser to former Labor Prime Minister Paul Keating, told him it would be 'if the rest of world decided it didn't want to finance the Australian current account deficit' (Taylor \& Uren 2010, 25)..$^{10}$ Henry did not see this as a likely scenario since, at the time, the risks to Australia's economy were seen as coming mainly from rising inflation (see, for example, Stevens 2009a).

Throughout late 2007 and into 2008, the global outlook worsened. At international meetings in March and April 2008, both the Prime Minister and Treasurer Wayne Swan received increasingly dire warnings about the global economic outlook, from leaders and officials including IMF Managing Director,

\footnotetext{
9 David Miliband, interview on ABC Television's Insiders, 2 May. http://www.abc.net.au/insiders/content/2010/s2888012.htm For the Prime Minister and senior Rudd ministers, the Australian-American Leadership Dialogue had provided opportunities to forge relationships from Opposition.

${ }^{10}$ Australian companies rely heavily on overseas capital to financed their imports and meet interest payments on private sector debt.
} 
Dominique Strauss-Kahn and Chairman of the US Federal Reserve Ben Bernanke. ${ }^{11}$ Similar views were being expressed by bankers, business people and economists, including expatriate Australians based in the United States (Taylor \& Uren 2010, 27-9). The sentiment among these players continued to be significantly worse than was being indicated in official data and advice. Stephen Kennedy (2009, 2) has noted that 'in a period when events are moving rapidly, leaders often hear about developments before they have filtered through their bureaucracies'. The new government, anxious to establish its authority and credibility, kept non-bureaucratic channels of advice open, taking regular soundings from business, industry, academia, as well as from overseas contacts about how the situation was unfolding. Rudd was determined that his government would not suffer the same fate as the Labor government of Jim Scullin, elected just two weeks prior to the crash on Wall Street that heralded the start of the Great Depression in 1929, and which endured the ignominy of being the only Australian government to be defeated after a single term (Taylor \& Uren 2010).

The collapse of Lehman Brothers on 15 September 2008, marked a turning point in the GFC. Confidence plummeted on fears of further bank failures, a freeze on credit and the prospect of a global meltdown. As Stiglitz (2010b) noted recently:

When the crisis struck, you have to understand no-one was sure how deep [or] how long it would to be. There was that moment of panic. Rightfully so, because the whole financial system was on the verge of collapse. In that context, what you need to do is act decisively.

Australian policy-makers not only acted decisively, but also pre-emptively. Within two days of Lehman's filing for bankruptcy, the Council of Financial Regulators, which includes the Reserve Bank, the Australian Prudential Regulatory Authority (APRA), the Australian Securities and Investments Commission (ASIC) and Treasury released its crisis plan. It was based on confidential analysis prepared in late 2007 about how a crisis involving one or more Australian financial institutions might be managed (Taylor and Uren 2010, 52). But it was also informed by lessons drawn from the 1997 Asian financial crisis - the critical importance of ensuring banks could access offshore finance to fund Australia's current account deficit. A temporary ban on short-selling was announced on 19 September and on 26 September, prompted by fears about the viability of second-tier banks, the government announced it would provide $\$ 4 B$ in support for the mortgage backed securities. In late September, Kevin Rudd, in New York to give a speech at the United Nations, called for the G20 to be used to

\footnotetext{
11 Kevin Rudd was reportedly 'shocked' when Strauss-Kahn warned that total losses from the sub-prime crisis could exceed a trillion dollars. Subsequently, that figure was revised to $\$ 3$ trillion (Taylor \& Uren 2010, 27).
} 
coordinate measures that would help stabilise the global financial system which was now in a panic, prompting governments in several countries to provide unlimited deposit guarantees.

On 7 October 2008, the Reserve Bank of Australia cut interest rates by a full percentage point, double the reduction canvassed at its Board meeting just a week before (Kennedy 2009, 3). It followed the previous month's 0.25 per cent easing of the cash rate. The Australian dollar plunged - losing 25 per cent of its value in the months following Lehman's collapse. On Friday 10 October, the Australian share market suffered its biggest decline since 1987, falling 8 per cent in one day, wiping an estimated $\$ 73$ billion off the value of share investments and, importantly, the superannuation savings of Australian households. The extraordinary instability that characterised markets from mid-September prompted the Reserve Bank to rethink its approach to monetary policy. According to the Governor, Glenn Stevens (2009a, 21):

Instead of the gradual easing of policy that we had been expecting would occur, as inflation gently subsided, the Board concluded... that it needed to be more aggressive in lowering rates. Australian households and businesses, understandably, began to react to events abroad. This meant that there was likely to be a much weaker outcome for demand and output - and hence a greater prospect of falling inflation - than had been expected up to that time. This change to the outlook was reflected in revisions to the central forecasts prepared by the Bank. It responded also to the risk that, in an environment of acute global financial strain and deleveraging, there could easily be a much weaker outcome for economic activity even than the one embodied in the reduced forecast.

Accordingly, the cash rate was reduced by a total of 300 basis points in the four months leading up to the end of 2008. It was lowered further in the early part of 2009.

Shortly after, following precedent from overseas, the government announced an immediate guarantee of all bank deposits under $\$ 1$ million. It would, for a fee, also provide an unlimited bank guarantee, designed to keep open access to wholesale borrowing and to support consumer confidence (Gruen and Clark 2010, 13; Gruen 2009, 6).

Rudd convened a crisis meeting of the Strategic Budget and Priorities Committee (SBPC) of Cabinet on 7 October. Treasurer Swan, in Washington at an IMF meeting, joined in by telephone, relaying the views of global policy-makers, particularly their advice that the government should be willing to 'act early'. According to Swan:

... the message is that the outlook is so risky that you shouldn't take the risk of not doing anything you can, that the damage of underestimating is bigger than the risk of overestimating... When you've got the Chief Economist of the IMF saying just pull every lever that you can... (quoted in Tingle, 2008, 24). 
Planning for stimulus

SBPC met in continuous session over the weekend of 11 to 12 October 2008 to develop the first stimulus plan. However, planning of the contents of a spending package had been underway since July. A crisis management team of ministers, officials and policy advisers from Treasury, the Department of the Prime Minister and Cabinet (PM\&C), the Reserve Bank and APRA had been established in August. Within Rudd's own department, the international economic policy group of officials from Treasury and the Department of Foreign Affairs and Trade (DFAT) was revived (Taylor and Uren 2010,69).

Rudd, Swan, selected ministerial staffers and the Treasury Secretary had been discussing spending options since a 'secret planning meeting' on 5 August. Senior ministerial staff from the Prime Minister's and Treasurer's offices were tasked with developing options for stimulus spending if monetary easing proved insufficient to buffer the Australian economy from the emerging threat. Uren and Taylor (2010) note:

This was extraordinarily early planning compared with other governments around the world. It was also extraordinary because nobody else knew. Not the cabinet. Not even Gillard and Tanner, the other two members of the supposed inner circle gang of four. The extreme sensitivity of the decisions meant Rudd's predilection for keeping things close was taken to extremes.

The advice from the Treasury Secretary had been to 'go hard, go early, go households' - a mantra reportedly extemporised by Henry on the spot, but which became the Prime Minister's organising principle (Taylor \& Uren 2010, 78). According to Treasury, stimulus spending should be 'timely, targeted and temporary' and outline a clear framework and timetable for returning the budget to surplus. ${ }^{12}$ The emphasis on cash payments quickly delivered was a lesson from the recession of the early 1990s, where stimulus spending had taken too long to have an effect and rates of unemployment had risen sharply as aggregate demand collapsed. Many of those who had lost their jobs never worked again. As the party of working people, Rudd believed Labor had an obligation to support jobs and keep people in employment. Supporting employment would be the primary goal of the government's fiscal response (see Taylor \& Uren 2010, 138).

The 2008 stimulus package was designed to provide immediate support to growth - through transfer payments to the most cash-constrained households; those most likely to spend additional income

12 These are regarded by Treasury as 'well accepted tenets of good discretionary fiscal policy' (see ABS 2009; Kennedy 2009, 3). 
(Kennedy 2009). Subsequent measures, if needed, would emphasise investment in infrastructure and skills for the expected recovery. The immediate priority was to prevent a loss of confidence that if unleashed, would become self-reinforcing. According to the Treasurer:

It's about getting ahead of where we are now, not reacting to it after it happens. It's actually about putting the fire out before it starts (quoted in Tingle 2008, 25).

The government's \$10.4B (1 per cent of GDP) 'Economic Security Strategy', was announced on 14 October 2008. It comprised \$8.7B in cash payments to low income households; \$1.5B for housing construction and $\$ 187 \mathrm{M}$ for training places. It targeted the weak sectors of consumption and housing, which together comprised 60 per cent of the Australian economy. Five million households received cash payments within a period of eight weeks, through Centrelink, the federal government's delivery agency, providing much needed support for retailers in the lead-up to Christmas. ${ }^{13} \$ 4.7 \mathrm{~B}$ of spending on infrastructure projects was brought forward.

By any measure the scope and extent of the government's intervention was audacious. It went harder and farther than had been conceived during discussions or was indicated by the official forecasts. The size of the package was the choice of the Prime Minister and Treasurer. It was an intuitive judgment, born of political instinct, reflecting Rudd's inclination always to be prepared for the worst case:

...we had to be in the business of making a difference and under those circumstances there are no halfmeasures. Either you don't act or you do. The worst thing you can do in public policy terms is to half-act; and you will be run over in the middle of the road (quoted in Taylor \& Uren 2010, 80).

In the circumstances, Rudd's pessimism proved more accurate than the forecasts, which were continually being revised downwards as the global economy plumbed new and more dangerous depths.

The government shifted to a crisis footing. From 20 October 2008 to the end of January 2009, senior ministers met daily with their advisers to review overnight developments on international markets - in person, by telephone or via video link. Constantly in contact with international counterparts and reviewing the increasingly negative assessments of international organisations and economists, the Prime Minister likened the situation to 'a rolling national security crisis' (see Gordon 2008).

Global conditions continued to deteriorate. The IMF issued a bleak forecast for world growth, urging governments in countries that could afford it to immediately implement government spending in the

${ }^{13}$ Retail trade grew by 4 per cent in December 2008, having shown no growth earlier in 2008. By October 2009, retail trade was 5.4 per cent higher than its pre-stimulus level in November 2008 (Gruen 2009b, 4). 
order of 2 per cent of GDP to support demand. Though it wrestled with the domestic politics of putting the budget into deficit, the Prime Minister and Treasurer concluded the dangers of rising unemployment more than outweighed the political risks. Throughout December and January work on a second stimulus package progressed in earnest. Conceived mainly in ministerial offices and with limited reference to public service advice, the \$42B 'National Building and Jobs Plan' (Taylor and Uren 2010, 141) was announced on 3 February 2009. It targeted infrastructure spending - $\$ 14.6 \mathrm{~B}$ for schools, \$6.6B for social and defence housing; \$3.9B for energy efficiency measures; a tax break of \$2.7B to support business investment and $\$ 890 \mathrm{M}$ for road, rail and small community infrastructure projects. The schools spending, which provided to build or upgrade a building in every Australian school, was designed to stimulate construction across local communities. It represented the biggest investment in education in Australian history - education is primarily the responsibility of state and territory (subnational) governments, but funding responsibility is shared. Successful delivery would require close cooperation between Commonwealth and sub-national governments (see Moran 2009).

A third and final stimulus package formed part of the 2009/10 federal budget, delivered in May 2009. It comprised a \$22B infrastructure spending program.

\section{Foundations for Australia's performance}

There is broad agreement that Australia's economy was shielded by timely and effective policy responses - both monetary and fiscal (see, for example, Henry 2009; Stevens 2009a; Stiglitz 2010, 62). The Reserve Bank's dramatic easing of interest rates from October 2008, together with the rapid depreciation of the Australian dollar demonstrated the flexibility and effectiveness of the modern monetary policy framework in responding to macro-economic shocks (Gruen \& Clark 2010, 12; Kennedy 2009). Aggressive fiscal policy responses, implemented quickly, well ahead of other economies, supported demand at a time of global uncertainty and diminishing confidence.

Australia's financial system and particularly its banking system, continued to function during the crisis, providing a buffer from the turmoil on international markets. Henry $(2009 \mathrm{a}, 2)$ argues that the resilience of Australia's banking sector is due in no small part to the quality of our financial regulatory system, which has benefitted from significant reforms undertaken by successive governments'. These arrangements have been a long time in the making. The Treasurer acknowledged recently that 
'Australia's economic success during the global crisis was built on a 25 year program of comprehensive structural reform' (Swan 2010b, 4).

The prime ministerships of Hawke, Keating and Howard have been described as a 'golden generation of world leading economic policy reform' (Stutchbury 2010; for a detailed account see Kelly 2009). Under their leadership, reforms included: a progressive opening of Australia's economy to competition; the dismantling of protection and tariffs; competition policy reforms achieved through cooperation between Commonwealth, State and Territory governments under which markets were liberalised, government monopolies were dismantled and many of them sold off. They also included labour market reform with wage rises linked to productivity or delivered through retirement savings.

Since the 1980s, Australian governments have pursued broadly consistent economic policies. The floating of the Australian dollar in 1983 laid the foundations for the modern monetary policy framework that proved so effective in 2008. Indeed, according to Kennedy $(2009,4)$, it 'turned out to be one of the most important economic reforms in Australia's history. It has worked as an effective automatic stabiliser, curtailing demand in the good times and supporting it in the bad'. The second component of the monetary policy framework is an independent central bank, committed to medium term price stability. The commitment to a target range of two to three per cent inflation and formal assertion of Bank independence under the Howard government in 1996 helped Australia defeat inflation and significantly improve its competitive position (Kelly 2009, 322-7).

Leaders of both political persuasions also embraced prudent fiscal policy settings that favoured surplus budgets or, where deficits were deemed necessary to ameliorate economic downturns, a commitment to bring the budget back to surplus within a specified time period. Taken together, developments over the period 1983 to 2004 positioned Australia to become a flexible and resilient market economy able to withstand external shocks and to keep growing. This was evidenced first by its success in navigating the 1997 Asian financial crisis and, more recently, in preparing for and facing the GFC in 2008.

Australia's strong economic performance owes much to the policy-makers who determined and sold often reforms that were often painful and politically difficult, and the advisers who researched, developed and presented the options, persuaded ministers of their benefits and supported their adoption and implementation. The bi-partisan consensus that has characterised economic policymaking over recent decades is a mark of a political culture that is essentially pragmatic (Garnaut 2009; Kelly 2009). Australian politics is tough and adversarial, but is not polarised nor bedevilled by the often 
bitter and entrenched political differences and intellectual fashions that characterise policy-making in the United States (Garnaut 2009; Gruen 2009a, 62).

Reserve Bank Governor Glenn Stevens (2009b) has acknowledged the shared efforts of decisionmakers and the advisers (both partisan and non-partisan), noting:

Long-term investments in prudent fiscal and monetary frameworks paid off. A whole generation of policy-makers painstakingly worked to build credibility by taking decisions with a long-term perspective. The return was in a capacity to respond credibly to the downturn [in 2008] before it gathered much pace. The lesson here, then, is that those investments were worthwhile.

As this suggests, Australia's 'economic miracle' was no one-off feat of serendipity. The institutions of economic policy advice and decision-making shaped a long-term reform agenda that positioned Australia to enter the crisis of 2008 and 2009 from a position of relative economic strength (Gruen 2009b). In the Westminster tradition, these same institutions provided advice and support to the newlyelected Rudd ministry when it took over the reins of power in November 2007.

\section{Advice and decision-making during the crisis}

Australian ministers are generalists - neither Kevin Rudd, Wayne Swan, Julia Gillard or Lindsay Tanner, were economist or bankers. Instead, they rely on the expertise of their advisers. As a Westminister-style political system, Australia retains a professional, impartial career public service as a key institution. The agencies that advise on and implement economic policy are the regulatory agencies and particularly the Treasury; the independent Reserve Bank is responsible for monetary policy but works closely with policy and regulatory agencies.

Since the mid-1970s, official advisers have been supplemented by ministerial staff - partisan personal staff selected by ministers to work in their private offices. This development has been a response to overload and the demands of professional politics, driven by ministers from both major parties. Over a thirty year period, they have consciously sought to reduce their dependence on the public service, and have implemented reforms to make it more responsive to political direction and the priorities of the government of the day (Tiernan 2007). Ministerial staff are a crucial part of the contemporary system of advice - offering a proximate source of advice and support on policy as well as political matters. They are drawn from a range of career backgrounds and often include public servants seconded to the minister's office for their specialist knowledge and expertise. 
During the 2007 election campaign, Kevin Rudd promised that his government would restore Westminster traditions of independence and security of tenure. In contrast to his predecessor who had controversially sacked six departmental secretaries, Rudd guaranteed the positions of all and signalled that his ministers would work cooperatively with and respect the professionalism and impartiality of public service departments. The decision ensured a smooth transition and avoided the disruptions that had characterised the early months of the Howard government's tenure (Tiernan and Weller 2010). But the retirement of the Secretary of the Department of the Prime Minister and Cabinet, Dr Peter Shergold, and a delay of three months in the arrival of his successor, meant that the new Prime Minister formed close working relationship with the Treasury Secretary, Dr Ken Henry.

A career public service provides continuity and institutional memory; ensuring decision-makers have the capacity to take a longer term view. Senior officials advising the government during the crisis had a depth of experience that spanned almost thirty years. Henry, a taxation expert, had served as an economic adviser to Prime Minister Paul Keating, and had been deeply engaged in economic reform since the early 1980s. Dr David Gruen, Executive Director of the macro-economic policy group, was an expert on the Great Depression, who, in addition to his significant academic record, had spent 13 years with the Reserve Bank, including five as the head of economic research. Both have reflected on lessons they drew from earlier crises:

History may judge the first fiscal stimulation package was too early, history may judge it was too large, history may judge the configuration was wrong. But my view was that we needed to do something, it needed to be big, and we needed to do it quickly. What informed that was I lived through - as a policy adviser - the recession of the 1990s. The government in a recession can't tolerate inaction - the population can't tolerate inaction on the part of the government. The government needed to do something (Henry, quoted in ASB 2009).

At the time of the Great Depression, Australia's macroeconomic policy frameworks were tragically illequipped to cope with anything other than small, inconsequential macroeconomic or financial market shocks. Faced with a shock the size of the Great Depression, they were simply overwhelmed. The lessons learnt from that disastrous experience have informed the macroeconomic frameworks of today (Gruen \& Clark 2010, 18).

The Australian Treasury has a great tradition and corporate identity. While recent governments have complained about the policy capacity of the Australian Public Service (APS), Treasury has been something of an exception. It has maintained its investment in research and analytical capacity; and is seen as having used creative talent management and exchange programs to attract and retain high quality staff. Each year it recruits significant numbers of the brightest university graduates and 
maintains a reputation as a training ground for gaining critical skills that will accelerate a career in more lucrative sectors.

Senior ministerial staff were also central in determining the Rudd government's response to the global financial crisis (see, for example, Gordon 2008). In the Prime Minister's Office and in the office of the Treasurer, the most senior staff were engaged in information gathering, policy and options development and, in the case of the second stimulus package, took primary carriage of policy design. Rudd's office was notable for its relative youth and inexperience - yet he had on his staff advisers drawn from the public service including Dr Stephen Kennedy, a senior Treasury official, and an Economics Adviser, Dr Andrew Charlton, who had co-authored a book with Joseph Stiglitz and was in contact throughout the crisis with relevant international experts. The office of Treasurer Wayne Swan also had experienced senior people, with extensive experience and expertise in management consulting and government.

Ministers and their staff worked collaboratively with officials, first monitoring the crisis and later preparing the government's policy response. Departments and regulatory agencies together with staff of the independent Reserve Bank shared knowledge and data and ensured a steady flow of information and advice to leaders. Though initially slow to recognise the potential for the crisis to reach Australia, the public service demonstrated the value of its preparedness. In 2004 when the economy was strong, the Treasury held two workshops during which it 'war-gamed' how it would handle the next economic downturn when, inevitably, it came (Taylor \& Uren 2010, 72); similarly the Council of Financial Regulators' 2007 work on how a crisis in a major financial institution might be managed meant much of the pre-work was already done for the financial stabilisation measures implemented throughout late 2008.

The agencies of economic advice thus showed they had robust routines for working together; key individuals were well known to each other and were able to draw on and integrate lessons from long experience. This policy learning was crucial at key stages of the crisis: in gauging its severity and potential impacts on Australia; in shaping policy approaches that consciously sought to draw lessons from the 1990s; and in seeking to ensure that longer-term policy frameworks would not be compromised by emergency measures. Throughout, advisers and decision-makers consciously debated the options, united in their resolve to avoid the consequences of unemployment and 'mistakes' from past interventions (for a detailed account see Taylor \& Uren 2010). 
Ross Garnaut (2009, 143-44), himself a significant contributor to economic reforms as a public servant and senior ministerial staffer, emphasises the 'searing experiences' Australian policy-makers had faced in two earlier financial failures: the 1990s recession, particularly the impact on banks of tight monetary policies - when they lost the equivalent of 5 per cent of GDP. This left regulators with a high sensitivity to banking risk. The collapse of insurance giant $\mathrm{HIH}$ in 2001 prompted significant reforms to prudential regulation, including the creation of a single regulator - APRA, to guard against systemic risks. The Asian Financial Crisis was also decisive and still fresh in the memories of senior advisers. According to Garnaut $(2009,145)$ 'Australian officials emerged from the episode with clearer views on the importance of regulation to constrain destabilising speculation and financial sector risk'.

On matters of economic policy, Australian decision-makers have been served by a professional cadre of official (public service) advisers that is experienced and highly stable. This is partly a phenomenon of long-term governments, which has meant that since 1983, there have been five Prime Ministers (Hawke, Keating, Howard, Rudd and now Gillard) and five Treasurers. It also reflects the central importance of the Treasury and the key institutions of economic advice - both in maintaining their expertise, but in developing and retaining a supply of expert advisers with knowledge and skills. Stability is important as is the nature of the economic policy community in Australia - it comprises a relatively small group of people, who know each other and keep in touch.

Treasury Secretary Dr Ken Henry (quoted in ASB 2009) told a business audience recently that the global financial crisis 'turned out not to be much of a crisis at all for Australia. But it posed a very significant challenge for policy advisors and central banks.' He noted that crises of the kind experienced in 2008 come along from time to time - 'you can prepare for them to some extent. But the best capability that you bring to a crisis at the time is your experience and the conceptual framework that you've got'.

If experience and conceptual frameworks are the indicators of policy capacity, Australian decisionmakers were mostly well-served by their hybrid advisory model. Political and personal networks provided intelligence and early warning. During the crisis, they drew on the support of an advisory system that combined experience and institutional memory with the input of partisan advisers with academic credentials and personal links to the global policy community. In designing their pre-emptive and aggressive response, they benefitted from the continuity and institutional memory of an advisory system which had prepared for and consciously drew on the insights and lessons learned during earlier down-turns. The advisory system provided a basis for Australia's response to the GFC, but is not 
sufficient to explain its success. Political leadership was also crucial - a prime minister and cabinet willing to ask for and act on advice but also prepared to back their own judgment in framing the crisis response.

Political leadership during the crisis

Australian Prime Ministers differ from their counterparts in other Westminster systems. Here they are elected by their party-rooms and can be replaced if they lose the support of their colleagues (Weller 1985). Despite this, in Australia, as elsewhere, since the 1980s, power has centralised around the institution of prime minister. Prime ministers personify their governments (Rhodes, Wanna and Weller $2009,95)$ and, by dint of having led their party to electoral success, enjoy considerable authority. Their command of the resources and prerogatives of office enables them to be pre-eminent - much more than first among equals, but within constraints: time, attention, the capacity to gain and maintain political and electoral support (Tiernan and Weller 2010). Recent Australian prime ministers have bolstered their capacity to dominate their governments, through assiduous media management and by significantly augmenting the system of advice that supports them (see Tiernan 2006; 2008). A large and powerful Prime Minister's Office is an entrenched feature of the Australian core executive, sharing responsibility for supporting the leader with the Department of the Prime Minister and Cabinet (PM\&C), established almost 100 years ago. The constitutional guarantee of support from an expert, impartial career public service ensures a significant degree of continuity, and 'deep structures' are also evident in partisan elements, but the advisory system adapts to the priorities and working style of the leader (Tiernan 2007; 2008). Personalities and preferences matter, though they are tempered by the institutions and routines of governance and, in the early stages of a new government, by the time it takes for the system to adjust to the demands of a new prime minister.

Prime ministers set the rules for Cabinet, determining when and how it will meet, the structure of its committees and the agenda of issues that come before it. Under the Hawke, Keating and Howard governments, the Expenditure Review Committee (ERC) was the engine-room of economic policy and reform. The Rudd government also made extensive use of Cabinet committees as fora for policy development and to pre-digest complex issues. During the crisis, SBPC became the government's command centre, though occasionally the Prime Minister and Treasurer acted as a duumvirate, notably during initial discussions about the need for a stimulus package. It was flexible, adaptive and able to operate in a variety of modes and locations, making use of available technologies and drawing in whatever expertise and support was appropriate in the circumstances. Ultimately too, it was collective - 
the decisions taken became those of the government, supported by the rest of the Cabinet, even those not directly involved in deliberations.

Each prime minister brings to the role their skills and experience and a view about how they plan to approach it. Kevin Rudd came to the prime ministership with an ambitious reform agenda, a vision of Australia's place in the world and a network of contacts assiduously cultivated on his rise to the nation's top job. Rudd's background as a diplomat, senior public servant and ministerial staffer fashioned his views on how he would engage the advisory system. He respected and made use of the public service but recognised it was neither the sole nor the definitive source of advice. Rudd's disposition to prepare for the 'worst case' reveals the potential for personalised governance; he drew constantly on historical references and analogies - specifically the Labor Scullin government, in determining how his government should respond. His inclination to reach out directly to international colleagues and networks accounts in significant ways for the strength of his government's fiscal policy response.

Australian decision-makers have substantial capacity to shape advisory arrangements. While Rudd respected the public service, he did not revere it and was conscious of its limitations; nor did he and other ministers hesitate to reach beyond it for information and advice. By April 2008 the Prime Minister was publicly expressing concerns about the capacity of the APS, particularly its ability provide strategic advice, innovative and creative ideas and solutions to policy problems (Rudd 2008). The government's handling of the crisis reveals the extent to which leaders determine the nature and extent of engagement with official advisers. It also exposes their willingness to rely on staff in their private offices - as, for instance, characterised the design of the second stimulus package.

The extent and timing of the Rudd government's response is attributable to the actions of political leaders who chose providing support for employment and confidence as their primary policy goal. They were aware of risks in the size and speed of the package, but determined that these risks were preferable to a situation in which hundreds of thousands of Australians might lose their jobs. Personal experience and values were relevant here, as inevitably they are in decision-making.

\section{After the storm: Reflections on Australian governance}

I have argued in this paper that over short, medium and long term policy horizons, the institutions of economic advice and decision-making have helped foster a strong and resilient economy. The system of advice and support and political leadership during the crisis, underpinned Australia's success relative 
to other advanced economies. This does not preclude other explanations: Australia's mineral wealth, high commodity prices; the 'national psyche' that is relaxed and optimistic (see, for example, World Policy Institute 2009, 109); some element of luck - but is clear that policy frameworks and decisions both during the crisis and at critical points over the past quarter century positioned Australia well.

Despite its success in navigating Australia's economy through the worst ravages of the global downturn, throughout 2010 the government has confronted the political consequences of decisions taken quickly at the height of the crisis. In late June, Prime Minister, Kevin Rudd, who had enjoyed consistently high approval ratings since his election in 2007, was unceremoniously dumped overwhelmed by implementation and delivery problems with the stimulus programs, and criticised by colleagues for excessive centralisation and failure to consult. That is, for sustaining crisis decisionmaking approaches as the normal mode of governing.

A wave of optimism met Kevin Rudd's election as Prime Minister in November 2007. Throughout the first twenty-six months of his prime ministership, he sustained the highest approval ratings of any Australian leader, but the fall when it came, was precipitous. From March 2010 the polls plummeted. Claims of government waste and inefficiency dogged the programs designed in haste as part of its second stimulus package, the 'National Building and Jobs Plans'. Every day brought a new revelation of rorts and inefficiencies - not just in media reports but also in official assessments of various investigatory and oversight agencies and the Parliament that form the accountability framework of Australian governance. It raised questions in the public's mind about the government's competence, its capacity to deliver and its ability to manage the 'debt and deficit' incurred to fund the stimulus program.

At the general election of 21 August 2010, Australian voters delivered a hung Parliament, the first since 1940. Labor may have lost as many as 16 seats in the House of Representatives. At the time of writing, counting continues, but there is a very real prospect that Julia Gillard will win fewer seats than her Liberal opponent and be unable to form a minority government. Chief among the criticisms levelled as Labor contemplates defeat is its inability to 'sell' its achievements in having 'saved' Australia from the global financial crisis. Ironically, the situation her predecessor was so anxious to avoid - being, like Jim Scullin, overwhelmed by a financial crisis and bundled from office after a single term, looks like being realised. 


\section{References}

ABS 2010, Labour Force, Australia, June 2010. Catalogue No. 6202.0 http://www.abs.gov.au/ausstats/abs@.nsf/mediareleasesbyCatalogue/46DFE12FCDB783D9CA256B740082AA6 C?Opendocument [Accessed 9 July 2010].

ASB 2009, 'Rapid response to GFC saved Australia's economy. Meet the CEO with Ken Henry'. Australian School of Business, University of NSW. 2 November.

Colebatch, T. 2009, 'Balance of power'. The Age. 24 October.

Eslake, S. 2009, 'The global economic crisis of 2007-2009: An Australian perspective'. Economic Papers, Vol 28, No. 3, pp 226-238.

Garnaut, R. 2009, The Great Crash of 2008. Melbourne, Melbourne University Press.

Gordon, J. 2008, 'The men keeping Rudd afloat'. The Age. 2 November.

Gruen, D. 2009a, 'Reflections on the global financial crisis'. Address to the Sydney Institute. 16 June.

- 2009b, 'The return of fiscal policy'. Address to the Australian Business Economists Annual Forecasting Conference. 8 December.

Gruen, D. and Clark, C. 2010, 'What have we learnt? The Great Depression in Australia from the perspective of today'. Economic Analysis and Policy, Vol 40, No. 1, March. pp. 3-20.

Hawtrey, K. 2009, 'The global credit crisis: why have Australian banks been so remarkably resilient?' Agenda. Vol 16, No. 3, pp. 95-114.

Henry, K. 2009, 'The global financial crisis and the road to recovery'. Speech to the Australian Institute of Company Directors. 23 September.

Kelly, P. 2009, The March of the Patriots: The Struggle for Modern Australia. Melbourne, MUP.

Kennedy, S. 2009, 'Australia's response to the global financial crisis'. Speech to the Australia Israel Leadership Forum. 24 June.

Moran, T. 2009, Speech to the Institute of Public Administration Australia, Canberra, 15 July.

OECD 2010, 'Australia: moving to a seamless national economy'. Organisation for Economic Cooperation and Development, Policy Brief, February.

Rhodes, RAW, Wanna, J. and Weller, P. 2009, Comparing Westminster. Oxford, Oxford University Press.

Rudd, K. 2008, Address to Heads of Agencies and Members of the Senior Executive Service. Great Hall, Parliament House, Canberra, 30 April.

Stevens, G. 2009a, 'The Conduct of Monetary Policy in Crisis and Recovery' Address to the John Curtin Institute of Public Policy and the Financial Services Institute of Australasia Public Policy Breakfast Forum, Perth, 15 October.

— 2009b The Road to Prosperity' Address to the Economic and Social Outlook Conference, Melbourne, 5 November.

Stiglitz. J. 2010a, Freefall: Free Markets and the Sinking of the Global Economy. London, Allen Lane.

- 2010b, Interview on ABC 7.30 Report, 27 July. Available at: http://www.abc.net.au/7.30/content/2010/s2965891.htm

Stutchbury, M. 2010, 'Riding our China luck as real reform goes begging'. The Australian, 27 July. 
Swan, W. 2010a, Positioning Australia for the Future: Delivering the Next Wave of Critical Economic Reform. Address to the Capital Markets Leaders Summit. Parliament House, Canberra. 21 June.

-2010b, Emerging from the Crisis: the G20 and the Asia-Pacific. Address to the Canada 2020 and the Canadian Australian Chamber of Commerce. Toronto. 27 June.

Taylor, L. and Uren, D. 2010, Shitstorm: Inside Labor's Darkest Days. Melbourne, MUP.

Tiernan, A. 2007, Power Without Responsibility. Sydney, University of NSW Press.

— 2006, 'Advising Howard: interpreting changes in advisory and support structures for the Prime Minister of Australia'. Australian Journal of Political Science, Vol 41, No. 3, September, pp. 309-24.

Tiernan, A. and Weller, P. 2010, Learning to be a Minister: Heroic Expectations, Practical Realities. Melbourne, MUP.

Tingle, L. 2008, 'The Treasurer who looked into the void'. The Weekend Australian Financial Review. October 18-19, pp. 24-25.

Treasury 2007, Pre-Election Economic and Fiscal Outlook. 17 October, p. 1.

Uren, D. and Taylor, L. 2010, 'How Rudd bet the house'. The Australian. 19 June.

Weller, P. 1985, First Among Equals: Prime Ministers in Westminster Systems. Sydney, Allen \& Unwin. 